\title{
CHANGING LIGHTING AND FEEDING TIME TO ALLEVIATE THE DELETERIOUS EFFECT OF HOT ASSIUT SUMMER ON PERFORMANCE OF JAPANESE QUAIL
}

\author{
M. F. A. Farghly \\ Department of Animal and Poultry Production, Faculty of Agriculture, University \\ of Assiut, Egypt
}

\section{SUMMARY}

This study was conducted to investigate the effects of lighting and feeding time management (at morning or afternoon) on productive and reproductive performance of Japanese quail in the hot summer of Assiut. Two hundred and forty unsexed oneday old chicks were reared in batteries and assigned to 4 groups (60 birds leach). The birds of first and second groups ( $C$ and T1), were exposed to light at the morning (1000 to 2200) and fed twice daily at 1000 and $1600 \mathrm{~h}$ as well as 2200 and $0400 \mathrm{~h}$, respectively. The third and fourth groups (T2 and T3) were exposed to light at the afternoon (2200 to 1000) and fed twice daily at 1000 and $1600 \mathrm{~h}$ as well as at 2200 and $0400 \mathrm{~h}$, respectively. All the other conditions were the same during the experimental period. Birds were supplied with clean water all the time. The results showed that change feeding and lighting time to afternoon significantly $(P \leq 0.05)$ improved growth performance, body temperature, egg number, egg quality and fertility percentage. While, no significant differences $(P \leq 0.05)$ existed in hatchability, egg weight and egg components. In conclusion, feeding Japanese quail at afternoon coincide with light is a good and economical managerial tool to alleviate the harmful effects of high temperature stress during the summer season at Assuit.

Keywords: performance, feeding and lighting time, hot summer, Japanese quail.

\section{INTRODUCTION}

High temperature is considered one of the important factors affecting poultry production, consequently profitability during the summer in hot climates above $30^{\circ} \mathrm{C}$ especially in Upper Egypt. As temperature rises, the bird has to maintain the balance between heat production and heat loss, thus it will reduce its feed consumption by $5 \%$ for every $1{ }^{\circ} \mathrm{C}$ rise in temperature between $32-38^{\circ} \mathrm{C}$ to reduce heat from metabolism this lead to reduced growth rate as compared to its genetic potential (Geraert et al., 1996 and Morêki, 2008). Regard to the heat production associated with feeding, therefore, birds would be facing problematic conditions when the feeding is at around 1000-1100 h, as the heat of feed utilization coincides with the hottest part of the day (Wilson et al., 1989; Saiful et al., 2002; Yahav and Hurwitz, 1996).

Although the advanced developments in building design, ventilation and cooling management, we are still faced with eliminating high temperature effects. Many lighting and feeding manipulations have been proposed to prevent or lessen the production losses. Feeding and lighting time management could be used to overcome

Issued by The Egyptian Society of Animal Production 
the negative effects of high temperature on poultry performance during hot weather (Aengwanich, 2007; Gharib et al., 2008 and El-Badry et al., 2009). Light allows the bird to synchronize many essential functions, including body temperature and various metabolic pathways that facilitate feeding and digestion. As birds generally only eat during the photoperiod, heat production associated with birds feeding would be at this time. Therefore, birds would be facing problematic conditions when the lighting time is at midday, as the heat of feed utilization coincides with the hottest part of the day especially in hot climates. Feed withdrawal and darkening treatments at midday improved the respiration rate, body temperature and immune responses (Saiful et al., 2002 and El-Badry et al., 2009).

Several methods are available to alleviate the effect of high environmental temperature, consequently improve the productive and reproductive performance of poultry. Since it is expensive to cool poultry buildings, such methods are focused mostly on the managerial manipulations. Therefore, the main objective of this study is the management of feeding and lighting time to improve productive and reproductive performance of Japanese quail in the hot summer of Assiut.

\section{MATERIALS AND METHODS}

The present study was carried out at the poultry research farm of the Animal and Poultry Production Department, Faculty of Agriculture, Assiut University, Assiut, Egypt. The experiment lasted during summer season (from May to October 2010), where the environmental temperature ranged from 22.4 to $28.3{ }^{\circ} \mathrm{C}$ at night and 31.6 to $35.9^{\circ} \mathrm{C}$ at midday while, humidity was from 40.4 to $63.4 \%$ (Table 1). Two hundred and forty unsexed one-day old Japanese quail chicks (Coturnix coturnix japonica) were reared in batteries and assigned to 4 groups (60 birds /each). The birds of first and second groups ( $\mathrm{C}$ and $\mathrm{T} 1$ ), were exposed to light at the morning (1000 to 2200) and fed twice daily at 1000 and $1600 \mathrm{~h}$ as well as 2200 and $0400 \mathrm{~h}$, respectively. The third and fourth groups (T2 and T3) were exposed to light at the afternoon (2200 to 1000) and fed twice daily at 1000 and $1600 \mathrm{~h}$ as well as at 2200 and $0400 \mathrm{~h}$, respectively. All the other conditions were the same during the experimental period. Birds were supplied with clean water all the time. Birds per each group, 60 birds (30 males and 30 females), were housed in quail brooding batteries with dimensions of $86 \mathrm{X} \square 50 \mathrm{X} \square 25 \mathrm{~cm}$ pens from hatch until sexual maturity. Subsequently, the quail were transferred into productive battery individual cages $(20 \mathrm{X} \square 25 \mathrm{X} \square 30 \mathrm{~cm}$ ) throughout the laying period. The composition and calculated analysis of the experimental diets are shown in Table (2).

The newly hatched chicks were exposed to continuous lighting for $24 \mathrm{hrs} /$ day during the first 3 days of age. Thereafter, the photoperiod was decreased gradually (one hr/wk) to be adjusted to $12 \mathrm{hrs}$ (growing) and $16 \mathrm{hrs}$ (laying) lighting regimens with light intensities of 10 and 20 Luxes, respectively. The body weight (BW) on individual basis, at $0,4,8,12,16,20$ and 24 weeks of age was recorded. The average body weight gain (BWG) was calculated biweekly from 0 to 8 weeks of age. The feed consumption (FC) was calculated biweekly, from 0 to 24 weeks of age. The feed conversion values during the growing period ( $g$ feed/g gain, FCRg) were calculated periodically every four weeks, from 0 to 8 weeks of age. The feed conversion ratio values during the laying period ( $g$ feed/g egg mass, FCRe) were calculated periodically every four weeks, from 8 to 24 weeks of age. Egg weight, egg number and egg production as hen-housed production (HHP) were calculated 
periodically every four weeks, from 8 to 24 weeks of age. Body temperature $\left({ }^{\circ} \mathrm{C}\right)$ was measured by using a thermometer inserted into the rectum for 2 minutes at depth of $2 \mathrm{~cm}$ in midday biweekly. Dead birds were recorded daily and expressed as percentage during the experimental period.

Table 1. The overall means of indoor temperature and relative humidity values during the experimental period

\begin{tabular}{ccccccc}
\hline \multirow{2}{*}{$\begin{array}{c}\text { Intervals } \\
\text { (Month) }\end{array}$} & \multicolumn{3}{c}{ Temperature $\left(\mathbf{C}^{\circ}\right)$} & \multicolumn{3}{c}{ Humidity (\%) } \\
\cline { 2 - 7 } Max. & Min & Av. & Max. & Min. & Av. \\
\hline May & 31.6 & 22.8 & 27.2 & 63.4 & 42.1 & 52.8 \\
Jun & 32.7 & 24.6 & 28.7 & 62.2 & 41.4 & 51.8 \\
Jul & 35.4 & 26.2 & 30.8 & 61.3 & 41.2 & 51.3 \\
Aug & 35.9 & 28.3 & 32.1 & 60.9 & 40.4 & 50.7 \\
Sep & 34.8 & 26.2 & 30.5 & 61.8 & 41.4 & 51.6 \\
Oct & 33.8 & 23.6 & 28.7 & 62.5 & 41.8 & 52.2 \\
\hline Overall mean & $\mathbf{3 4 . 0}$ & $\mathbf{2 5 . 3}$ & $\mathbf{2 9 . 7}$ & $\mathbf{6 2 . 0}$ & $\mathbf{4 1 . 4}$ & $\mathbf{5 1 . 7}$ \\
\hline
\end{tabular}

Max $=$ Maximum Min= Minimum Av. = Average

Table 2. Composition and calculated analysis of the experimental diets

\begin{tabular}{lcc}
\hline \multicolumn{1}{c}{ Ingredients } & Starter (\%) & Layer (\%) \\
\hline Yellow corn & 53.0 & 52.3 \\
Soybean meal (44\%) & 34.6 & 31.7 \\
Concentrate & $12.0 *$ & $10.0 * *$ \\
NaCl & 0.25 & 0.50 \\
Dicalcium phosphate & 0.15 & 1.50 \\
Limestone & --- & 4.00 \\
\hline Total & $\mathbf{1 0 0}$ & $\mathbf{1 0 0}$ \\
\hline & Calculated analysis*** \\
\hline Protein (\%) & 26.0 & 23.6 \\
ME ( KCal/ Kg diet) & 2850 & 2775 \\
Calcium ( \%) & 0.90 & 2.75 \\
Available phosphorus (\%) & 0.45 & 0.75 \\
\hline
\end{tabular}

* Broiler concentrate contains: $52 \%$ crude protein $1.6 \%$ crude fiber6.1\%, ether extract $7 \%$, calcium 3.5\% available phosphorus $1.5 \%$ methionine, $2.1 \%$ methionine and cystine , $3.0 \%$ lysine $2416 \mathrm{kcal} / \mathrm{kg}$ metabolizable energy. Each Kilogram of broiler concentrate contains the following levels of vitamins and minerals: vit. A 130,000 IU; D3 26,000 IU; vit. E 120 IU; vit B12 $150 \mathrm{ug}$; vit. K3 MSB $16 \mathrm{mg}$; vit B2 $50 \mathrm{mg}$; capantothenate B3 $120 \mathrm{mg}$; nicotinic acid PP $250 \mathrm{mg}$; thiamine B1 $25 \mathrm{mg}$; folic acid $15 \mathrm{mg}$; betain-Choline- $\mathrm{HCl} 5000 \mathrm{mg}$; $\mathrm{Mn} 700$ mg;Zn 600 mg; Fe 400 mg;Cu 40 mg; Iodine 7 mg; Se 1.5 mg; B.H.T. 1250 mg; Zinc baciteracin $150 \mathrm{mg}$.

** The layer concentrate contains: Crude protein, 51.00\%- Lysine, 3.30\%- Crude fiber, $2.00 \%$ Calcium, 8.00\% -Crude fat ,6.40 \% - Available phosphorus,3.00\%- Methionine,1.7 \%-Salt, $3.19 \%$ - Methionine+Cystine,2.25\%- Metabolizable energy $2400 \mathrm{kcal} /$. Each Kilogram of layer concentrate contains the following levels of vitamins and minerals: Vit. A, 10000 IU - Folic acid , $10 \mathrm{mg}$-Vit. E, $100 \mathrm{mg}$ - Biotin, $500 \mathrm{mg}$ - Vit. D3, 2500 IU - Chorine chloride $5000 \mathrm{mg}$ - Vit. K, $25 \mathrm{mg}$ - Iron, $400 \mathrm{mg}$ - Vit. B1, $100 \mathrm{mg}$ - Zinc,560 mg- Vit. B2,40 mg- Copper, $5 \mathrm{mg}-$ Vit. B6, 15mg - Iodine, 3 mg- Vit. B12, $200 \mathrm{mg}$ - Selenium, 1mg-Pantothenic acid, $100 \mathrm{mg}-$ Manganese, $620 \mathrm{mg}$ - Niacin, $400 \mathrm{mg}$ - Antioxidant $75 \mathrm{mg}$.

*** Calculated according to NRC (1994).

During the period from 12 to 24 weeks of the experiment, 360 fresh-laid eggs were taken, every four weeks, from each group to measure egg quality 
characteristics. Egg weight was recorded to the nearest 0.1 gram on the same day of collection using a special automatic digital balance. The length and width of eggs were determined using a sliding caliper and egg shape index was determined according to Reddy et al. (1979) as egg shape index = (width of egg/length of egg)x 100. All eggs were broken gently on a glass surface. The height of thick albumen and yolk were measured using a micrometer, as described by Brant and Shrader (1952). The diameter of yolk was measured, using a sliding caliper. The yolk was separated from the albumen and weighted. Shells with membranes were dried and weighed to the nearest $0.01 \mathrm{gm}$. Haugh units were calculated for individual eggs from the egg weight and albumen height values (Doyon et al., 1986), using the following formula: Haugh unit $=100 \log (\mathrm{H}-1.7 \mathrm{x}$ w $0.37+7.6)$ Where: $\mathrm{H}=$ the observed height of the albumen in millimeters and $\mathrm{W}=$ weight of egg $(\mathrm{g})$.

Yolk index was calculated by dividing yolk's height/ yolk's diameter x100. Shell thickness of the dried shell (without membranes) was measured using shell thickness apparatus and the average was recorded ( 0.01 millimeters). The albumen weight was calculated by subtracting shell and yolk weight from egg weight. The egg components were expressed as percentages of the egg weight. Eggs laid in all experimental groups were collected daily and stored 7 days at $15-18^{\circ} \mathrm{C}$ and $70-75 \%$ relative humidity before incubation. Four hatches were performed at 12, 16, 20 and 24 weeks of age. The incubation was carried out using automatic Patersime setter and hatcher. The fertility and hatchability percentages were calculated as follow: Fertility $(\%)=$ number of fertile eggs $\times 100 /$ total set eggs. True hatchability $(\%)=$ number of hatched chicks $\mathrm{x} 100 /$ total fertile eggs.

Economical efficiency was based on the costs of the feed consumed and the income/bird (body weight and fertile egg production). The net revenue per bird is estimated as the difference between the total income/bird (LE), (growth and fertile egg production) and the total costs of feed and others. The costs of the used diets were calculated according to the actual prices prevailing in the Egyptian market during the time of experiment.

Statistical analysis was performed according to one-way analysis of variance in this experiment using GLM procedure of SAS, version 6.12, 1996. The following model was used for analysis of variance:

Where:

$$
\mathbf{Y}_{\mathrm{ij}}=\boldsymbol{\mu}+\mathbf{S}_{\mathrm{i}}+\mathbf{e}_{\mathrm{ij}}
$$

$$
\begin{array}{ll}
\mathrm{Y} \mathrm{ij}=\text { observation, } & \mu=\text { overall mean, } \\
\mathrm{Si}=\text { treatment effect, } & \mathrm{e} \mathrm{ij}=\text { experimental errors. }
\end{array}
$$

Duncan separation of means method (1955) was used to detect significant differences among means of different groups. The percentages of HHP, fertility and hatchability were transformed to Arcsin values before the statistical analysis.

\section{RESULTS AND DISCUSSSION}

\section{Body weight (BW) and Body weight gain (BWG):}

The results presented in Table (3), showed significant differences $(\mathrm{P} \leq 0.05)$ in BW and BWG for all the experimental groups at all studied ages except at 0,2 and 4 weeks of age for BW as well as at 0-2 weeks of age for BWG. The overall mean of $\mathrm{T} 1, \mathrm{~T} 2$ and $\mathrm{T} 3$ had a significantly higher $(\mathrm{P} \leq 0.05)$ ABWG than those of $\mathrm{C}$ by about $6.4,9.7$ and $6.4 \%$, respectively. 
Table 3. Means $\pm \mathrm{SE}$ of growth traits of Japanese quail as affected by feeding and lighting time

\begin{tabular}{|c|c|c|c|c|c|}
\hline \multirow{2}{*}{ Traits } & \multirow{2}{*}{$\begin{array}{c}\text { Age } \\
\text { (wks) }\end{array}$} & \multicolumn{4}{|c|}{ Treatments } \\
\hline & & $\mathbf{C}$ & T1 & $\mathrm{T} 2$ & T3 \\
\hline \multirow{9}{*}{ Body weight (g) } & 0 & $7.61 \pm 0.91$ & $7.55 \pm 0.61$ & $7.72 \pm 0.92$ & $7.81 \pm 0.61$ \\
\hline & 2 & $53.6 \pm 2.11$ & $55.8 \pm 1.88$ & $56.4 \pm 1.96$ & $54.4 \pm 2.66$ \\
\hline & 4 & $123.6 \pm 2.11$ & $126.2 \pm 3.22$ & $128.2 \pm 3.14$ & $125.3 \pm 3.22$ \\
\hline & 6 & $166.4^{\mathrm{b}} \pm 3.38$ & $174.8^{\mathrm{ab}} \pm 4.22$ & $180.4^{\mathrm{a}} \pm 2.31$ & $175.1^{\mathrm{ab}} \pm 4.52$ \\
\hline & 8 & $196.6^{\mathrm{b}} \pm 3.42$ & $208.0^{\mathrm{a}} \pm 5.56$ & $216.8^{\mathrm{a}} \pm 3.52$ & $209.2^{\mathrm{a}} \pm 4.22$ \\
\hline & 12 & $198.2^{\mathrm{b}} \pm 4.68$ & $209.8^{\mathrm{a}} \pm 4.62$ & $218.2^{\mathrm{a}} \pm 3.21$ & $211.4^{\mathrm{a}} \pm 3.26$ \\
\hline & 16 & $197.9^{\mathrm{b}} \pm 5.25$ & $208.6^{\mathrm{ab}} \pm 5.22$ & $219.7^{\mathrm{a}} \pm 4.12$ & $214.2^{\mathrm{a}} \pm 4.02$ \\
\hline & 20 & $202.0^{\mathrm{c}} \pm 4.02$ & $212.2^{\mathrm{b}} \pm 4.66$ & $221.9^{\mathrm{a}} \pm 3.12$ & $215.8^{\mathrm{ab}} \pm 4.12$ \\
\hline & 24 & $205.0^{\mathrm{c}} \pm 3.22$ & $212.8^{\mathrm{bc}} \pm 3.11$ & $222.8^{\mathrm{a}} \pm 4.22$ & $215.6^{\mathrm{ab}} \pm 3.71$ \\
\hline \multirow{4}{*}{$\begin{array}{l}\text { Body weight } \\
\text { gain } \\
\text { (g/bird/day) }\end{array}$} & $0-2$ & $3.29 \pm 0.22$ & $3.45 \pm 0.16$ & $3.47 \pm 0.11$ & $3.33 \pm 0.16$ \\
\hline & $2-4$ & $4.99^{c} \pm 0.31$ & $5.03^{\mathrm{b}} \pm 0.10$ & $5.13^{\mathrm{a}} \pm 0.15$ & $5.01^{\mathrm{b}} \pm 0.21$ \\
\hline & $4-6$ & $3.10^{c} \pm 0.12$ & $3.47^{\mathrm{b}} \pm 0.26$ & $3.73^{\mathrm{a}} \pm 0.12$ & $3.56^{\mathrm{b}} \pm 0.12$ \\
\hline & $6-8$ & $2.20^{\mathrm{c}} \pm 0.11$ & $2.36^{\mathrm{b}} \pm 0.22$ & $2.60^{\mathrm{a}} \pm 0.22$ & $2.44^{\mathrm{ab}} \pm 0.11$ \\
\hline \multicolumn{2}{|c|}{ Overall mean } & $3.37^{b} \pm 0.16$ & $3.58^{\mathrm{a}} \pm 0.32$ & $3.73^{a} \pm 0.16$ & $3.60^{a} \pm 0.21$ \\
\hline \multirow{9}{*}{$\begin{array}{c}\text { Feed } \\
\text { consumption } \\
\text { (g/bird/day) }\end{array}$} & 0 - 2 & $8.66 \pm 0.55$ & $8.88 \pm 0.47$ & $8.49 \pm 0.51$ & $8.80 \pm 0.68$ \\
\hline & $2-4$ & $12.72 \pm 0.72$ & $12.99 \pm 0.72$ & $12.82 \pm 0.66$ & $13.11 \pm 0.69$ \\
\hline & $4-6$ & $14.62 \pm 0.83$ & $14.58 \pm 0.62$ & $14.92 \pm 0.74$ & $15.12 \pm 0.98$ \\
\hline & $6-8$ & $17.00 \pm 0.81$ & $17.18 \pm 0.92$ & $17.58 \pm 0.81$ & $17.66 \pm 1.01$ \\
\hline & $8-12$ & $16.99 \pm 1.01$ & $17.11 \pm 0.92$ & $18.24 \pm 1.03$ & $18.32 \pm 1.11$ \\
\hline & $12-16$ & $18.73 \pm 1.21$ & $19.01 \pm 0.82$ & $19.68 \pm 0.91$ & $20.12 \pm 1.01$ \\
\hline & $16-20$ & $20.39 \pm 1.10$ & $20.69 \pm 0.78$ & $21.69 \pm 0.68$ & $22.11 \pm 0.91$ \\
\hline & $20-24$ & $20.65 \pm 0.91$ & $20.71 \pm 0.93$ & $21.97 \pm 0.92$ & $22.12 \pm 0.78$ \\
\hline & all mean & $16.22 \pm 0.89$ & $16.39 \pm 0.96$ & $16.92 \pm 0.88$ & $17.17 \pm 1.0$ \\
\hline \multirow{4}{*}{$\begin{array}{c}\text { Feed } \\
\text { conversion } \\
\text { (g feed/g gain) } \\
\text { (FCRg) }\end{array}$} & 0 - 2 & $2.63 \pm 0.11$ & $2.57 \pm 0.10$ & $2.44 \pm 0.10$ & $2.64 \pm 0.08$ \\
\hline & $2-4$ & $2.54 \pm 0.18$ & $2.58 \pm 0.11$ & $2.50 \pm 0.08$ & $2.59 \pm 0.09$ \\
\hline & $4-6$ & $4.78^{\mathrm{a}} \pm 0.20$ & $4.20^{\mathrm{b}} \pm 0.08$ & $4.00^{\mathrm{b}} \pm 0.10$ & $4.25^{\mathrm{b}} \pm 0.20$ \\
\hline & $6-8$ & $7.90^{\mathrm{a}} \pm 0.12$ & $7.27^{\mathrm{ab}} \pm 0.21$ & $6.76^{\mathrm{b}} \pm 0.20$ & $7.25^{\mathrm{ab}} \pm 0.31$ \\
\hline \multicolumn{2}{|c|}{ Overall mean } & $4.46^{\mathrm{a}} \pm 0.18$ & $4.15^{\mathrm{ab}} \pm 0.13$ & $3.92^{\mathrm{ab}} \pm 0.11$ & $4.18^{\mathrm{ab}} \pm 0.14$ \\
\hline \multirow{4}{*}{$\begin{array}{c}\text { Feed } \\
\text { conversion } \\
\text { (g feed/g egg } \\
\text { mass) (FCRe) }\end{array}$} & $8-12$ & $3.59^{\mathrm{a}} \pm 0.13$ & $3.10^{\mathrm{b}} \pm 0.09$ & $2.89^{b} \pm 0.09$ & $3.49^{\mathrm{a}} \pm 0.12$ \\
\hline & 12- 16 & $2.77^{\mathrm{a}} \pm 0.05$ & $2.57^{\mathrm{ab}} \pm 0.07$ & $2.46^{\mathrm{b}} \pm 0.08$ & $2.63^{\mathrm{ab}} \pm 0.07$ \\
\hline & $16-20$ & $2.61 \pm 0.10$ & $2.49 \pm 0.11$ & $2.49 \pm 0.14$ & $2.68 \pm 0.14$ \\
\hline & $20-24$ & $2.65 \pm 0.14$ & $2.41 \pm 0.11$ & $2.35 \pm 0.13$ & $2.65 \pm 0.12$ \\
\hline \multicolumn{2}{|c|}{ Overall mean } & $2.90 \pm 0.11$ & $2.64 \pm 0.95$ & $2.55 \pm 0.11$ & $2.86 \pm 0.11$ \\
\hline \multicolumn{6}{|c|}{$\begin{array}{l}\text { a---c Means within row followed by different superscripts are significantly different }(\mathrm{P} \leq 0.05) \text {. } \\
\mathrm{C}=\text { Birds exposed to light at morning }(1000 \text { to } 2200) \text { and fed twice daily at } 1000 \text { and } 1600 \mathrm{~h} . \\
\text { T1 = Birds exposed to light at morning }(1000 \text { to } 2200) \text { and fed twice daily at } 2200 \text { and } 0400 \mathrm{~h} \text {. } \\
\text { T2 = Birds exposed to light at afternoon (2200 to } 1000) \text { and fed twice daily at } 1000 \text { and } 1600 \mathrm{~h} \text {. } \\
\text { T3 = Birds exposed to light at afternoon (2200 to } 1000) \text { and fed twice daily at } 2000 \text { and } 0400 \mathrm{~h} \text {. } \\
\text { When temperatures remain at a high level for a long period of time, birds will } \\
\text { find it increasingly difficult to reduce their heat production leading to decrease feed } \\
\text { consumption resulting in lowering growth rate. Researches have shown that each } 3^{\circ} \mathrm{C}\end{array}$} \\
\hline
\end{tabular}


increase in ambient temperature over $33^{\circ} \mathrm{C}$ will reduce growth by $0.9 \%$ in chicken (Meltzer, 1987; Yahav and Hurwitz, 1996). Similar results were reported by Abbas et al. (2007) and Gharib et al. (2008) who found that body weight of chicken reared under high temperature and intermittent light program was significantly higher than the continuous light. Also, Donkoh et al. (1989) found that when birds received lighting during the night they had significantly higher body weight gain compared to other groups. Classen et al. (2004a) demonstrated that the darkness period tend to limit growth rate due to preventing of regular access to feed and water.

Regarding feeding time, feeding birds during hot part of day led to increasing the heat load, due to the heat produced during feed metabolism. This leads to a remarkable depression in the available metabolizable energy for growth (Marai et al., 2006). Our results are agreement with the results of Hassan et al. (2003), Bouvarel et al. (2004), and Farghly (2010) who stated that birds fed at the afternoon had significantly $(\mathrm{P} \leq 0.05)$ higher body weight and body weight gain than those of birds fed at midday. On the contrary, Harms (1991) and Samara et al. (1996) found a decrease in body weight and body weight gain when birds were fed at the afternoon.

\section{Feed consumption (FC) and feed conversion (FCR):}

The obtained results presented in Table (3), showed insignificant differences in feed consumption (FC) values in the experimental four groups at all ages studied. However, the differences in average FCR during the experimental periods from 4-6 and 6-8 weeks of age for growth (FCRg) as well as from 8-12 and 12-16 weeks of age for egg $(\mathrm{FCRe})$ were significant $(\mathrm{P} \leq 0.05)$.

It is known that poultry prefer to eat during the light period, although they will eat during darkness if insufficient periods of light are provided (Simmons, 1982). Therefore, birds would be facing problematic conditions when the lighting time is at midday, as the heat of feed utilization coincides with the hottest part of the day. So, change of the lighting time from morning to evening was among managerial alternatives used to improve FCR of hens maintained under hot climate (Bootwalla et al., 1983 and Wilson and Keeling, 1991). Donkoh et al. (1989) found that birds received lighting during the night had significantly higher feed consumption compared to the other groups.

Most of the reduction in feed consumption and feed efficiency in hot climate is due to reduced maintenance requirement, consequently, decrease the appetite of birds (Marai et al., 2006 and Morêki, 2008). Our results coincided with the findings of Keshavarz (1998), Veltmann et al. (1984) and Farghly (2010). They found that FC and FCR for broilers fed at the afternoon was superior to the other groups. However, Roland et al. (1972) found that feeding the Japanese quail during the period from 1400 to $2200 \mathrm{~h}$ increased FCR above those of quail fed from 0600 to $1400 \mathrm{~h}$.

\section{Body temperature (BT):}

Data presented in Table (4), show significant differences $(\mathrm{P} \leq 0.05)$ in body temperature $\left({ }^{\circ} \mathrm{C}\right)$ between the experimental four groups starting at 8 weeks of age. The average body temperature (ABT) of $\mathrm{T} 1, \mathrm{~T} 2$ and $\mathrm{T} 3$ groups were significantly $(\mathrm{P} \leq 0.05)$ lower than those of $\mathrm{C}$ group at $8,12,20$ and 24 weeks of age. The ABT of $\mathrm{T} 2$ and $\mathrm{T} 3$ groups were significantly $(\mathrm{P} \leq 0.05)$ lower than those of $\mathrm{C}$ group at 16 weeks of age. 
Table 4. Means $\pm \mathrm{SE}$ of Body temperature and mortality rate of Japanese quail as affected by feeding and lighting time

\begin{tabular}{|c|c|c|c|c|c|}
\hline \multirow{2}{*}{ Traits } & \multirow{2}{*}{$\begin{array}{l}\text { Age } \\
\text { (wks) }\end{array}$} & \multicolumn{4}{|c|}{ Treatments } \\
\hline & & $\mathrm{C}$ & T1 & T2 & T3 \\
\hline \multirow{9}{*}{$\begin{array}{l}\text { Body temp. } \\
\left(\mathrm{C}^{\circ}\right)\end{array}$} & $\mathbf{0}$ & $39.82 \pm 0.27$ & $39.68 \pm 0.27$ & $39.98 \pm 0.08$ & $39.89 \pm 0.40$ \\
\hline & 2 & $40.58 \pm 0.18$ & $40.72 \pm 0.25$ & $40.81 \pm 0.30$ & $40.71 \pm 0.06$ \\
\hline & 4 & $40.92 \pm 0.30$ & $40.88 \pm 0.16$ & $40.48 \pm 0.90$ & $40.79 \pm 0.30$ \\
\hline & 6 & $40.96 \pm 0.12$ & $40.92 \pm 0.23$ & $40.78 \pm 0.14$ & $40.92 \pm 0.07$ \\
\hline & 8 & $41.44^{\mathrm{a}} \pm 0.18$ & $40.96^{\mathrm{b}} \pm 0.10$ & $40.72^{b} \pm 0.07$ & $40.78^{b} \pm 0.18$ \\
\hline & 12 & $42.10^{\mathrm{a}} \pm 0.13$ & $41.14^{b} \pm 0.23$ & $41.10^{b} \pm 0.18$ & $41.12^{b} \pm 0.19$ \\
\hline & 16 & $42.21^{\mathrm{a}} \pm 0.14$ & $41.78^{\mathrm{ab}} \pm 0.10$ & $41.12^{c} \pm 0.16$ & $41.34^{b c} \pm 0.20$ \\
\hline & 20 & $41.92^{\mathrm{a}} \pm 0.18$ & $41.32^{\mathrm{b}} \pm 0.01$ & $40.78^{\mathrm{b}} \pm 0.17$ & $41.27^{\mathrm{b}} \pm 0.20$ \\
\hline & 24 & $42.21^{\mathrm{a}} \pm 0.16$ & $41.66^{\mathrm{b}} \pm 0.14$ & $40.85^{c} \pm 0.13$ & $41.32^{b c} \pm 0.14$ \\
\hline \multirow{3}{*}{$\begin{array}{l}\text { Mortality } \\
\text { rate (\%) }\end{array}$} & $0-8$ & 5.80 & 4.23 & 3.40 & 3.20 \\
\hline & $8-24$ & 3.82 & 3.42 & 2.22 & 2.82 \\
\hline & $0-24$ & 9.62 & 7.65 & 5.62 & 6.02 \\
\hline \multicolumn{6}{|c|}{$\begin{array}{l}\text { a----c Means within row followed by different superscripts are significantly different }(\mathrm{P} \leq 0.05) \text {. } \\
\mathrm{C}=\text { Birds exposed to light at morning (1000 to } 2200) \text { and fed twice daily at } 1000 \text { and } 1600 \mathrm{~h} \text {. } \\
\mathrm{T} 1=\text { Birds exposed to light at morning }(1000 \text { to } 2200) \text { and fed twice daily at } 2200 \text { and } 0400 \mathrm{~h} \text {. } \\
\text { T2 }=\text { Birds exposed to light at afternoon }(2200 \text { to } 1000) \text { and fed twice daily at } 1000 \text { and } 1600 \mathrm{~h} . \\
\text { T3 }=\text { Birds exposed to light at afternoon }(2200 \text { to } 1000) \text { and fed twice daily at } 2000 \text { and } 0400 \mathrm{~h} .\end{array}$} \\
\hline
\end{tabular}

The body temperature of a bird varies between 40 and $42^{\circ} \mathrm{C}$, depending on the time of day (before and after feeding, night time), feather cover, brooding, and environmental temperature (Donkoh, 1989). During darkness period, melatonin reduces heat production by lowering body temperature and regulating heat dissipation (Shoukry et al., 1993; Rozenboim et al., 1998 and Apeldorn et al., 1999). El-Badry et al. (2009) found that feed withdrawal and darkness improved the respiration rate, body temperature and immune responses of muscovy ducks. However, Carmen et al. (1991) found that food withdrawal or darkness during heat stress had no significant effect on body temperature.

Heat production increased after 3 to $5 \mathrm{hrs}$ of feeding. This is associated with about $+1^{\circ} \mathrm{C}$ rise in body temperature (Cave, 1981; Leeson and Summers, 2000, and Avila et al., 2003a). Also, Wiernusz and Teeter (1993) and Koh et al. (2000) observed that heat production and body temperature increased with feed consumption. Aperdoorn et al. (1999) reported that chickens had lower heat production during the second and third hours of the dark period than the chickens under continuous light.

\section{Mortality rate:}

The data presented in Table (4), showed that, the mortality rate of the four studied groups ranged between 3.2 and $5.8 \%$ for growing period and between 2.2 and $3.8 \%$ for laying period and between 5.6 and $9.6 \%$ for all the experimental period. Introduction of photoperiod during temperate climate, consequently feeding is associated with potential welfare benefits, including lower physiological stress, improved immune response, increased sleep and increased overall activity (Gordon, 1994; Davis et al., 1997 and Classen et al., 2004b). 
The present results agree with the observations of Marai et al. (2002) who found that exposing birds to high temperature during midnight increased the mortality rate. On the contrary, Avila et al. (2003b) found that the feeding time had no effect on mortality. Naughton et al. (2002) and Bölükbasi and Emsen (2006) found that during heat exposure period, under the continuous light, the mortality rate was almost twice as compared with intermittent lighting program.

\section{Egg production (EP):}

The data presented in Table (5) revealed significant differences $(\mathrm{P} \leq 0.05)$ in the egg number (EN) and hen housed production (HHP) among birds of the experimental groups at all ages studied. The total of EN and average HHP for T2 group was significantly $(\mathrm{P} \leq 0.05)$ higher than that of $\mathrm{C}$ group. The overall mean of HHP and total $\mathrm{EN}$ for $\mathrm{T} 2$ group was significantly $(\mathrm{P} \leq 0.05)$ higher than that of $\mathrm{C}$ group by 13.7 and $13.6 \%$, respectively.

Table 5. Means \pm SE of egg number, hen housed production and egg weight for Japanese quail as affected by feeding and lighting time

\begin{tabular}{|c|c|c|c|c|c|}
\hline \multirow{2}{*}{ Traits } & \multirow{2}{*}{ Periods } & \multicolumn{4}{|c|}{ Treatments } \\
\hline & & $\mathrm{C}$ & $\mathrm{T} 1$ & $\mathrm{~T} 2$ & T3 \\
\hline \multirow{5}{*}{$\begin{array}{c}\text { Egg number } \\
\text { (egg/hen/28 } \\
\text { days) }\end{array}$} & P1 (8 -12w) & $12.6^{b} \pm 0.63$ & $14.4^{\mathrm{ab}} \pm 1.1$ & $16.4^{\mathrm{a}} \pm 0.50$ & $13.7^{b} \pm 0.70$ \\
\hline & P2 (12 -16w) & $17.5^{b} \pm 0.3$ & $18.8^{\mathrm{ab}} \pm 0.70$ & $20.2^{\mathrm{a}} \pm 0.07$ & $19.4^{\mathrm{a}} \pm 0.80$ \\
\hline & P3 (16- $20 \mathrm{w})$ & $19.6^{\mathrm{b}} \pm 0.42$ & $20.5^{\mathrm{ab}} \pm 0.50$ & $21.5^{\mathrm{a}} \pm 0.40$ & $20.5^{\mathrm{ab}} \pm 0.53$ \\
\hline & P4 (20- $24 w)$ & $19.2^{\mathrm{b}} \pm 0.7$ & $20.3^{\mathrm{ab}} \pm 0.64$ & $21.9^{\mathrm{a}} \pm 0.40$ & $19.9^{b} \pm 0.50$ \\
\hline & Total & $69.0^{b} \pm 2.0$ & $74.1^{\mathrm{ab}} \pm 2.9$ & $79.9^{\mathrm{a}} \pm 1.4$ & $73.6^{\mathrm{ab}} \pm 2.50$ \\
\hline \multirow{5}{*}{$\begin{array}{c}\text { Egg weight } \\
\text { (g) }\end{array}$} & P1 (8 -12 w) & $10.5 \pm 0.20$ & $10.7 \pm 0.12$ & $10.8 \pm 0.07$ & $10.7 \pm 0.25$ \\
\hline & P2 (12 -16w) & $10.8 \pm 0.24$ & $11.0 \pm 0.20$ & $11.2 \pm 0.13$ & $11.1 \pm 0.24$ \\
\hline & P3 (16- $20 w)$ & $11.2 \pm 0.30$ & $11.4 \pm 0.18$ & $11.4 \pm 0.07$ & $11.3 \pm 0.21$ \\
\hline & P4 (20- $24 \mathrm{w})$ & $11.4 \pm 0.40$ & $11.9 \pm 0.12$ & $12.0 \pm 0.13$ & $11.8 \pm 0.21$ \\
\hline & $\begin{array}{c}\text { Overall } \\
\text { mean }\end{array}$ & $10.9 \pm 0.30$ & $11.3 \pm 0.15$ & $11.4 \pm 0.11$ & $11.2 \pm 2.50$ \\
\hline \multirow{5}{*}{$\begin{array}{l}\text { Hen housed } \\
\text { production } \\
(\text { HHP ,\%) }\end{array}$} & P1 (8 -12w) & $45.1^{b} \pm 2.3$ & $51.6^{\mathrm{ab}} \pm 3.9$ & $58.4^{\mathrm{a}} \pm 1.8$ & $49.1^{b} \pm 2.50$ \\
\hline & P2 (12 -16w) & $62.6^{\mathrm{b}} \pm 1.03$ & $67.2^{\mathrm{ab}} \pm 2.5$ & $72.1^{\mathrm{a}} \pm 0.24$ & $69.4^{\mathrm{a}} \pm 2.70$ \\
\hline & P3 (16- $20 \mathrm{w})$ & $70.1^{\mathrm{b}} \pm 1.50$ & $73.3^{\mathrm{ab}} \pm 1.7$ & $76.9^{\mathrm{a}} \pm 1.4$ & $73.4^{\mathrm{ab}} \pm 1.90$ \\
\hline & P4 (20- $24 \mathrm{w})$ & $68.6^{\mathrm{b}} \pm 2.50$ & $72.6^{\mathrm{ab}} \pm 2.6$ & $78.1^{\mathrm{a}} \pm 1.5$ & $71.1^{\mathrm{b}} \pm 1.71$ \\
\hline & $\begin{array}{c}\text { Overall } \\
\text { mean }\end{array}$ & $61.6^{b} \pm 1.82$ & $66.1^{\mathrm{ab}} \pm 2.60$ & $71.4^{\mathrm{a}} \pm 1.2$ & $65.7^{\mathrm{ab}} \pm 2.20$ \\
\hline $\begin{array}{l}\text { a----b Means } \\
\mathrm{C}=\text { Birds exp } \\
\text { T1 }=\text { Birds exp } \\
\text { T2 = Birds exp } \\
\text { T3 = Birds exp }\end{array}$ & $\begin{array}{l}\text { thin row followe } \\
\text { ed to light at mor } \\
\text { ed to light at mo } \\
\text { sed to light at aft } \\
\text { sed to light at aft }\end{array}$ & $\begin{array}{l}\text { y different supe } \\
\text { ig ( } 1000 \text { to } 220 \\
\text { ng ( }(1000 \text { to } 220\end{array}$ & $\begin{array}{l}\text { scripts are signi } \\
\text { and fed twice } \\
\text { and fed twice } \\
0 \text { ) and fed twic } \\
0 \text { ) and fed twic }\end{array}$ & $\begin{array}{l}\text { cantly different } \\
\text { aily at } 1000 \text { and } \\
\text { aily at } 2200 \text { anc } \\
\text { daily at } 1000 \text { a } \\
\text { daily at } 2000 \text { a }\end{array}$ & $\begin{array}{l}\leq 0.05) \\
600 \mathrm{~h} \\
400 \mathrm{~h} \\
1600 \mathrm{~h} \\
0400 \mathrm{~h}\end{array}$ \\
\hline
\end{tabular}

The harmful effects of high temperature on egg production are not only due to a reduction in feed consumption but also by a disruption of hormones responsible for ovulation and a decrease in responsiveness of granulosa cells to luteinizing hormone (Donoghue et al., 1989 and Novero, 1991). Laying hens increase their calcium intake during the evening as eggshells are normally formed during this time (Morêki, 2008). Also, Hsu et al. (1998) found that high temperature decreases significantly egg production and egg weight. On the contrary, Farmer et al. (1983); Bootwalla et al. 
(1983) and Brake and Peebles (1986) found that afternoon feeding in chickens increased the egg weight.

The obtained results are in agreement with observations of Wilson et al. (1989), who reported that in feeding the birds during the hot time of the day leads to heat stress, due to the heat increment that happen during feed metabolism. The findings of Duncan and Hughes (1975) and Hassan et al. (2003) suggest that quail fed from 1400 to $2200 \mathrm{~h}$ had higher egg production rate. Moreover, the herein results agree with observations of Balnave (1977), Avila et al. (2003b) and Farghly (2010) who found that the afternoon feeding resulted in a higher rate of egg production. On the contrary, Brake and Peebles (1986) and Harms (1991) found that feeding hens during the afternoon caused a reduction in egg production. However, Brake (1988), Wilson and Keeling (1991) and Samara et al. (1996) who, noted that afternoon feeding had no effect on egg production.

\section{Egg quality traits:}

Data presented in Table (6), indicated that, there are significant differences $(\mathrm{P}>0.05)$ in average of egg weight (AEW), egg shape index (ESI), egg yolk index (EYI) and egg components (Albumen $\%$, Yolk\%, Shell\%) due to change lighting and feeding time. However, significant differences $(\mathrm{P} \leq 0.05)$ in the shell thickness $(\mathrm{ST})$ and Haugh units $(\mathrm{HU})$ were present among birds in the experimental groups. The average ST of T2 group had significantly higher $(\mathrm{P} \leq 0.05)$ than those of $\mathrm{C}$ group. $\mathrm{T}$

Table 6. Means $\pm \mathrm{SE}$ of egg quality traits and egg components for Japanese quail as affected by feeding and lighting time

\begin{tabular}{lcccc}
\hline \multirow{2}{*}{ Traits } & C & T1 & T2 & T3 \\
\cline { 2 - 5 } & $10.92 \pm 0.26$ & $10.94 \pm 0.21$ & $11.1 \pm 0.20$ & $11.0 \pm 0.32$ \\
\hline Egg weight (g) & $74.61 \pm 0.82$ & $75.1 \pm 1.50$ & $76.1 \pm 0.52$ & $75.2 \pm 0.36$ \\
Egg shape index (\%) & $54.80 \pm 1.1$ & $55.0 \pm 0.4$ & $55.6 \pm 0.5$ & $55.2 \pm 0.5$ \\
Egg yolk index (\%) & $89.42^{\mathrm{b}} \pm 0.6$ & $90.3^{\mathrm{ab}} \pm 0.70$ & $91.3^{\mathrm{a}} \pm 0.33$ & $89.1^{\mathrm{b}} \pm 0.33$ \\
Haugh units & $18.5^{\mathrm{b}} \pm 0.24$ & $19.4^{\mathrm{ab}} \pm 0.42$ & $19.9^{\mathrm{a}} \pm 0.32$ & $19.4^{\mathrm{ab}} \pm 0.41$ \\
Egg shell thickness (x 0.01 mm) & $54.62 \pm 1.0$ & $55.30 \pm 1.1$ & $55.36 \pm 1.11$ & $55.11 \pm 1.1$ \\
Albumen (\%) & $36.88 \pm 1.64$ & $35.56 \pm 0.41$ & $35.41 \pm 1.61$ & $36.31 \pm 0.9$ \\
Yolk (\%) & $8.45 \pm 0.40$ & $9.11 \pm 0.50$ & $9.21 \pm 0.33$ & $8.62 \pm 0.38$ \\
Shell (\%) & a----b Means within row followed by different superscripts are significantly different $(\mathrm{P} \leq 0.05)$. \\
C = Birds exposed to light at morning (1000 to 2200) and fed twice daily at 1000 and $1600 \mathrm{~h}$. \\
T1= Birds exposed to light at morning (1000 to 2200) and fed twice daily at 2200 and $0400 \mathrm{~h}$. \\
T2 = Birds exposed to light at afternoon (2200 to 1000) and fed twice daily at 1000 and $1600 \mathrm{~h}$. \\
T3 = Birds exposed to light at afternoon (2200 to 1000) and fed twice daily at 2000 and $0400 \mathrm{~h}$.
\end{tabular}

The average Haugh unit $(\mathrm{HU})$ of the $\mathrm{T} 2$ group was significantly $(\mathrm{P} \leq 0.05)$ higher than those of $\mathrm{C}$ and $\mathrm{T} 3$ groups. High temperature may produce adverse effects on egg quality traits, such as eggshell thickness and egg specific gravity by reducing calcium intake and metabolism, interfering with the calcium carbonate formation in the shell and upsetting the acid-base balance in the blood and limits the amount of CO3 available for eggshell formation (Teeter and Smith, 1986; Odom et al., 1986; Hsu et al., 1998 and Morêki, 2008).

An additional advantage of feeding at the afternoon is the availability of calcium in the digestive system during shell formation at night, consequently shell quality will improve. The obtained results are in partial agreement with observations of 
Lennards et al. (1981), Bootwalla et al. (1983), Brake and Peebles (1986), Brake (1988) and Harms (1991). They reported that feeding hens at the afternoon had an important role in the ability of laying hens to calcify eggshells as compared with morning feeding. However, Wilson and Keeling (1991) and Samara et al. (1996) found that feeding time had no effect on egg components and quality.

Fertility and hatchability (\%):

The results presented in Table (7) revealed significant $(\mathrm{P} \leq 0.05)$ increase in the average of fertility percentage ( $\mathrm{F} \%$ ) of $\mathrm{T} 1$ group over the $\mathrm{C}$ group at 16, 20 and 24 weeks of age. Also, the overall mean of $\mathrm{F} \%$ for $\mathrm{T} 2$ exceeded significantly $(\mathrm{P} \leq 0.05)$ that of $\mathrm{C}$ by $9.0 \%$. It is well known that high ambient temperature increase body temperature, which has negative effect on gamete formation and the fertilization process resulting in low fertility (Morêki, 2008).

Table 7. Means $\pm \mathrm{SE}$ of fertility and hatchability of Japanese quail eggs as affected by feeding and lighting time

\begin{tabular}{|c|c|c|c|c|}
\hline \multirow{2}{*}{$\begin{array}{c}\text { Age } \\
\text { (wks) }\end{array}$} & \multicolumn{2}{|c|}{ Fertility (\%) } & \multicolumn{2}{|c|}{ Hatchability (\%) } \\
\hline & T1 & $\mathrm{T} 2$ & T1 & T2 \\
\hline 12 & $81.3 \pm 3.82 \quad 83.9 \pm 4.31$ & $87.1 \pm 2.92 \quad 85.8 \pm 4.62 \quad 61.6 \pm 1.69$ & $63.1 \pm 3.88$ & $62.8 \pm 3.62 \quad 60.6 \pm 2.33$ \\
\hline 16 & $83.6^{\mathrm{b}} \pm 1.6188 .5^{\mathrm{ab}} \pm 2.12$ & $91.6^{\mathrm{a}} \pm 3.0189 .4^{\mathrm{ab}} \pm 3.61 \quad 65.9 \pm 1.86$ & $66.3 \pm 2.42$ & $68.8 \pm 3.11 \quad 64.2 \pm 4.22$ \\
\hline 20 & $86.5^{\mathrm{b}} \pm 1.9890 .2^{\mathrm{ab}} \pm 2.75$ & $94.6^{\mathrm{a}} \pm 1.9392 .4^{\mathrm{ab}} \pm 2.32 \quad 66.2 \pm 2.57$ & $69.0 \pm 4.72$ & $67.7 \pm 3.61 \quad 65.1 \pm 3.21$ \\
\hline 24 & $82.2^{\mathrm{b}} \pm 2.7290 .6^{\mathrm{ab}} \pm 2.52$ & $92.9^{\mathrm{a}} \pm 2.5991 .4^{\mathrm{ab}} \pm 3.1565 .2 \pm 1.74$ & $66.6 \pm 3.66$ & $69.5 \pm 2.51 \quad 64.3 \pm 3.11$ \\
\hline $\begin{array}{c}\text { Overall } \\
\text { mean }\end{array}$ & $83.4^{\mathrm{b}} \pm 1.8888 .30^{\mathrm{ab}} \pm 2.52$ & $291.6^{\mathrm{a}} \pm 3.1189 .8^{\mathrm{ab}} \pm 2.7564 .7 \pm 3.22$ & $66.2 \pm 4.11$ & $67.2 \pm 3.42 \quad 63.6 \pm 3.22$ \\
\hline $\begin{array}{l}\mathrm{a}-----\mathrm{b} \mathrm{M} \\
\mathrm{C}=\text { Bird } \\
\mathrm{T} 1=\text { Birc } \\
\mathrm{T} 2=\mathrm{Bir} \\
\mathrm{T} 3=\mathrm{Bir}\end{array}$ & $\begin{array}{l}\text { ans within row followed } \\
\text { exposed to light at morn } \\
\text { exposed to light at mort } \\
\text { exposed to light at afte } \\
\text { exposed to light at afte }\end{array}$ & $\begin{array}{l}\text { by different superscripts are signific } \\
\text { aing ( } 1000 \text { to } 2200) \text { and fed twice da } \\
\text { ning ( }(1000 \text { to } 2200) \text { and fed twice da } \\
\text { rnoon }(2200 \text { to } 1000) \text { and fed twice } \\
\text { rnoon }(2200 \text { to } 1000) \text { and fed twice }\end{array}$ & $\begin{array}{l}\text { cantly differ } \\
\text { aily at } 1000 \\
\text { aily at } 2200 \\
\text { daily at } 100 \\
\text { daily at } 200\end{array}$ & $\begin{array}{l}\text { ent }(P \leq 0.05) \\
\text { and } 1600 \mathrm{~h} . \\
\text { and } 0400 \mathrm{~h} . \\
0 \text { and } 1600 \mathrm{~h} \text {. } \\
0 \text { and } 0400 \mathrm{~h} \text {. }\end{array}$ \\
\hline
\end{tabular}

A relationship between mating time and lighting time, consequently feeding time was observed. Mating activity is usually in the highest rate in late afternoon (Harms, 1991; Leeson and Summers, 2000). Similar results of Brake (1988), Hassan et al. (2003), Petek (2008) and Farghly et al. (2010) were reported. They stated that feeding hens in the afternoon resulted in higher fertility than those fed in the morning. However, Bootwalla et al. (1983) found no effect of feeding time on fertility. The improvement of egg quality and egg production of quail fed at the afternoon may be the reason for the improved fertility. As for hatchability, the obtained results are in disagreement with the observations of McDaniel et al. (1979), Brake (1988) and Farghly (2010) who reported that afternoon feeding improves hatchability. However, the findings of Farmer et al. (1983) indicated that afternoon feeding decreased hatchability.

\section{Economical efficiency:}

The data presented in Table (8), showed that, birds fed from 2000 to $2400 \mathrm{~h}$ and exposed to light at afternoon (T2) had higher economical efficiency as compared to the other three groups (C, T1 and T3) during growing and laying periods, since, it amounted 100, 108.6, 112.2 and 104.5 for growing period as well as100, 116.0, 125.0 and 108.4 for laying period, respectively. Gordon (1994), Morris (2004) Campo et al. (2007), and Farghly et al. (2010) reported similar results.

Table 8. Economical efficiency of Japanese quail as affected by feeding and lighting time 


\begin{tabular}{|c|c|c|c|c|c|}
\hline \multirow{2}{*}{\multicolumn{2}{|c|}{ Items }} & \multicolumn{4}{|c|}{ Treatment } \\
\hline & & $\mathbf{C}$ & T1 & T2 & T3 \\
\hline \multicolumn{6}{|l|}{ Growing period: } \\
\hline \multirow{2}{*}{$\begin{array}{l}\text { Total costs/ bird } \\
\text { (L.E) }\end{array}$} & Total feed consumption (kg/bird) & 0.95 & 0.96 & 0.98 & 0.99 \\
\hline & Total feed costs (L.E) & 2.14 & 2.16 & 2.22 & 2.23 \\
\hline \multicolumn{2}{|c|}{$\begin{array}{lll}\begin{array}{l}\text { Total } \\
\text { (bird/L.E) }\end{array} & \text { revenue } & \begin{array}{l}\text { Selling price of bird at } 8 \text { weeks of age } \\
\text { (L.E) }\end{array}\end{array}$} & 4.71 & 5.00 & 5.20 & 5.02 \\
\hline \multicolumn{2}{|c|}{ Net revenue/ bird/L.E (without constant costs $=25 \%$ ) } & 2.58 & 2.83 & 2.99 & 2.80 \\
\hline \multicolumn{2}{|c|}{ Economical efficiency/ bird (EE) } & 1.20 & 1.31 & 1.35 & 1.26 \\
\hline \multicolumn{2}{|c|}{ Relative economical efficiency/ bird (REE) } & 100.0 & 108.6 & 112.2 & 104.5 \\
\hline \multicolumn{6}{|c|}{ Laying period: } \\
\hline \multirow{2}{*}{ Total costs/ bird/L.E } & Total feed consumption (kg/bird) & 2.15 & 2.17 & 2.28 & 2.31 \\
\hline & Total feed costs (L.E) & 4.30 & 4.34 & 4.57 & 4.63 \\
\hline \multirow{2}{*}{$\begin{array}{l}\text { Total } \\
\text { bird/L.E }\end{array}$} & Fertile egg number/hen & 57.6 & 65.4 & 73.2 & 66.1 \\
\hline & Selling price for fertile eggs/hen/L.E & 20.2 & 22.9 & 25.6 & 23.1 \\
\hline \multicolumn{2}{|c|}{ Net revenue/ bird/L.E (without constant costs= 25\%) } & 15.85 & 18.56 & 21.06 & 18.51 \\
\hline \multicolumn{2}{|c|}{ Economical efficiency/ bird (EE) } & 3.69 & 4.28 & 4.61 & 4.00 \\
\hline \multicolumn{2}{|c|}{ Relative economical efficiency/ bird (REE) } & 100.0 & 116.0 & 125.0 & 108.4 \\
\hline \multicolumn{6}{|c|}{$\begin{array}{l}\mathrm{C}=\text { Birds exposed to light at morning }(1000 \text { to } 2200) \text { and fed twice daily at } 1000 \text { and } 1600 \mathrm{~h} . \\
\mathrm{T} 1=\text { Birds exposed to light at morning }(1000 \text { to } 2200) \text { and fed twice daily at } 2200 \text { and } 0400 \mathrm{~h} . \\
\text { T2 }=\text { Birds exposed to light at afternoon (2200 to } 1000) \text { and fed twice daily at } 1000 \text { and } 1600 \mathrm{~h} . \\
\text { T3 }=\text { Birds exposed to light at afternoon }(2200 \text { to } 1000) \text { and fed twice daily at } 2000 \text { and } 0400 \mathrm{~h} .\end{array}$} \\
\hline
\end{tabular}

It could be concluded that the feeding birds at afternoon and lighting (T2) was more economically efficient as compared to other groups. This could be attributed to the superiority of $\mathrm{T} 2$ in growth and egg performance as well as having adequate percentages of fertility. In addition, $\mathrm{T} 2$ decreased the body temperature of birds, which was positively reflected on the health condition of the birds. The feeding and lighting at afternoon gave the best results in terms of performance and total net returns and therefore should be encouraged.

\section{REFERENCES}

Abbas A.O., A.E. Gehad, G.L. Hendricks, H.B.A. Gharib and M.M. Mashaly, 2007. The effect of lighting program and melatonin on the alleviation of the negative impact of heat stress on the immune response in broiler chickens. International $\mathrm{J}$. of Poult. Sci., 6: 651-660.

Aengwanich W., 2007. Effects of High Environmental Temperature on the Productive Performance of Thai Indigenous, Thai Indigenous Crossbred and Broiler Chickens. International J. of Poult. Sci., 6: 349-353.

Apeldorn E.J., J.W. Schrama, M. M. Mashaly and H. K. Parmentier, 1999. Effect of melatonin and lighting schedule on energy metabolism in broiler chickens. Poult. Sci., 78:223-227.

Avila V., J.A. Penz, P. Brum, P. Rosa, A Guidoni and E. Figueiredo, 2003a. Performance of female broiler breeders submitted to different feeding schedules. Rev. Bras. Cienc. Avic., 6:5. 
Avila V., J.A. Penz; P. Rosa; P. Brum; A. Guidoni, and M.Ledur, 2003b. Influence of feeding time on sexual maturity and carcass composition in female broiler breeders. Rev. Bras. Cienc. Avic., 5:3.

Balnave D., 1977. The effect of energy restriction on laying hens given either a single morning or single evening meal. Br. Poult. Sci., 18: 115-119.

Bölükbasi S.C. and H. Emsen, 2006. The effect of diet with protein and intermittent lighting on ascites induced by cold temperatures and performance in broilers. International J. Poult. Sci., 5: 988-991.

Bootwalla S., H.R. Willson and R.H. Harms, 1983. Performance of broiler breeders on different feeding systems. Poult. Sci., 62: 2321-2325.

Bouvarel I., B. Guillot, P. Larroude, B. Boutten, C. Leterrier, F. Merlet, M. Vilarino, L. Roffidal, S. Tesseraud, J. Castaing and M. Picard, 2004. Sequential feeding programs for broiler chickens twenty-four- and forty-eight-hour cycles. Poult. Sci., 83: 49-60.

Brake J.D., 1988. Relationship of time and strain to egg shell quality and hatchability in broiler breeders. Poult. Sci., 67: 538-543.

Brake J.D. and E.D Peebles, 1986. Effects of strain and time of feeding on reproductive performance and shell quality of broiler breeders. Poult. Sci., 65 (Suppl. 1):156. (Abstr.).

Brant A.W. and H.L Shrader, 1952. How to measure internal egg quality? Bureau of Animal Industry. Agric. Res. Administration, U.S. Dept. of Agric., Circular P. A. 202.

Campo J.L., M.G. Gil, S. G. Da'vila, and I. Muñoz, 2007. Effect of Lighting Stress on Fluctuating Asymmetry, Heterophil-to-Lymphocyte Ratio, and Tonic Immobility Duration in Eleven Breeds of Chickens. Poult. Sci. 86:37-45.

Carmen A.F., M.G. Macleod, and E.M. Anderson, 1991. Alleviation of a cute heat stress by food withdrawal or darkness. Br. Poult. Sci., 32: 219-225.

Cave, NA., 1981. Effect of diurnal programs of nutrient intake on performance of broiler breeder hens. Poult. Sci., 60: 1287-1292.

Classen H.L., C.B. Annett, K.V. Schwean-Lardner, R. Gonda and D. Derow, 2004a. The effects of lighting programs with twelve hours of darkness per day provided in one, six or twelve hour intervals on the productivity and health of broiler chickens. Br. Poult. Sci., 45:S31-32.

Classen H.L., C.B. Annett, K.V. Schwean-Lardner, R. Gonda and D. Derow, 2004b. The effects of lighting programmes with twelve hours of darkness per day provided in one, six or twelve hour intervals on the productivity and health of broiler chickens. Br. Poult. Sci., 45: S31-32.

Davis J., P.B. Thomas and T.D. Siopes, 1997. More evidence for light-dark growing. Broiler Industry, February: 31-32.

Donkoh A., C.Comfort, A Atuahene and G. Kese, 1989. Effect of feeding regimen and lighting pattern on the performance of broiler chickens in the hot, humid tropics . Br. Poult. Sci., 30: 403 - 406.

Donkoh A., 1989. Ambient temperature: a factor affecting performance and physiological response of broiler chickens. International J. Biometeorol. 33:259-265.

Duncan, D.B., 1955. Multiple range and multiple F test. Biometrics 11: 1-42.

Duncan, J.H. and B.O. Hughes, 1975. Feeding activity and egg formation in hens laid continuously. Br. Poult. Sci., 16: 145-155.

El-Badry A. S. O., W. A. H. Ali, Kh. A. A. Ali and M. F. S. Hanna, 2009. Effect of feed withdrawal and darkening periods on physiological and immunological 
responses of Muscovy ducks during high environmental temperature. Egypt. Poult. Sci., 29:307-321.

Farghly M.F.A., 2010. Productive and reproductive performance of Japanese quail as affected by time of feed in hot climate. Assiut Vet. Med. J. 56:202-224.

Farmer, M.; D.A. Roland, and M.K. Eckman, 1983. Calcium metabolism in broiler breeder hens. 2. The influence of the time of feeding on calcium status of the digestive system and egg shell quality in broiler breeders. Poult. Sci., 62: 465-471.

Geraert P.A., J.C.F. Padilha and S. Guillaumim, 1996. Metabolic and endocrine changes induced by chronic heat exposure in broiler chickens: growth performance, body weight and energy retention. Br. J. Nutr. 75: 195-204.

Gharib H.B.A., A.A. Desoky, and M.A. El-Menawey, 2008. The role of photoperiod and melatonin on alleviation of the negative impact of heat stress on broilers. International J. of Poult. Sci. 7 8: 749-756.

Gordon, S.H., 1994. Effects of daylength and increasing daylength programmes on broiler welfare and performance. World's Poult. Sci. J. 50:269-282.

Harms R.H., 1991. The influence of changing time of feeding on performance of broiler breeder hens. Poult. Sci., 70: 1695-1698.

Hassan S.M., M.E.Mady, A.L.Cartwright, H.M. Sabri and M.S. Mobarak, 2003. Effect of early feed restriction on reproductive performance in Japanese quail (Coturnix coturnix japonica). Egypt. Poult. Sci., 23: 1163-1169.

Hsu J.C., C.Y. Lin and P.W. Chiou, 1998. Effects of ambient temperature and methionine supplementation of a low protein diet on the performance of laying hens. Animal Feed Sci., and Technology; 74:289-299.

Keshavarz K., 1998. Investigation on the possibility of reducing protein, phosphorus, and calcium requirements of laying hens by manipulation of time of access to these nutrients. Poult. Sci., 77: 1320-1332.

Koh K., Y. Karasawa and K. Sekigawa, 2000. Effects of feeding on body temperature, heart rate and shivering threshold in growing broilers acutely exposed to the cold. Faculty of Agric., Shinshu Univ., Minamiminowa, Nagano 399- 4598, Japan. Poult. Sci.. 37: 12-18.

Leeson S.A. and J.D Summers, 2000. Broiler breeder production. univ. Books, Guelph, Ontario, Canada, N1H6N8.

Lennards R., D.A.S. Roland, and J.A. McGuire, 1981. The relationship of serum calcium to shell weight and other criteria in hens laying a low or high incidence of shell-less eggs. Poult. Sci., 60: 2501- 2505.

Marai I.F.M., A.A. Askar and L.B. Bahgat, 2006. Tolerance of New Zealand White and Californian doe rabbits at first parity to the sub-tropical environment of Egypt Livestock Science 104 (2006) 165-172.

Marai I.F.M., A.A.M. Habeeb and A.E. Gad, 2002. Rabbits productive, reproductive and physiological performance traits as affected by heat stress: a review. Livest. Prod. Sci., 78: 71-90.

McDaniel, G.R.; D.A. Roland, and M.A. Coleman, 1979. The effect of egg shell quality on hatchability and embryonic mortality. Poult. Sci., 58: 10-13.

Meltzer, A. 1987. Acclimatization to ambient temperature and it's nutritional consequences. World's Poult. Sci., 43:33-44.

Morêki J. C., 2008. Feeding strategies in poultry in hot CLIMATE. Non-Ruminants Division, Department of Animal ProductionP/Bag 0032, Gaborone, Botswana

Morris T.R., 2004. Environmental control for layers. World's Poult. Sci. J. 60:163-175. 
National Research Council, 1994. Nutrient Requirements of Poultry.9th rev.ed. National Academy Press, Washington,D.C.

Naughton M.P., A. Henderson, M.C. Mirabelli, R. Kaiser, J.L. Wilhelm, S.M. Kieszak, C.H. Rubin and M.A. McGeehin, 2002. Heat-related mortality during a 1999 heat wave in Chicago. Am. J. Prev. Med., 22: 221-227.

Novero R.P., M.M. Beck, E.W. Gleaves, A. L. Johnson and J. A. Deshazer, 1991. Plasma progesterone, luteinizing hormone concentrations and granulose cell responsiveness in heat-stressed hens. Poult. Sci., 70:2335-2339.

Odom T.W., P.C. Harrison and W.G. Bottje, 1986. Effects of thermal-induced respiratory alkalosis on blood ionized calcium levels in the domestic hen. Poult. Sci. 65:570-573.

Petek, 2008. Effect of feeding time on the reproductive performance of Pharaoh quail and Pekin duck. Department of Zootechnics, Faculty of Veterinary Medicine, University of Uludag, Bursa, Turkey.

Reddy P.M., V.R. Reddy, C.V. Reddy and P.S.P Rap, 1979. Egg weight, shape index and hatchability in Khaki Campbell duck egg. Ind. Poult. Sci., 14: 26-31.

Roland D.A., D.R. Sloan and R.H. Harms, 1972. Calcium metabolism in the laying hen. 3. Pattern of feed (calcium) intake as influenced by time of day and oviposition. Poult. Sci., 51: 1388-1391.

Rozenboim I., L.Miara, and D Wolfenson, 1998. The thermoregulatory mechanism of melatonin induced hypothermia in chicken. Am. J. Physiol. 274 (Reg. Integrat. Comp. Physiol.43): R232R236.

Saiful I.M., M.Fujita and T. Ito, 2002. Effect of feeding levels and physical activities on heat production in laying hens under different ambient temperatures. Poult. Sci., 39: 118-125.

Samara M.H., K.R. Robbins and M.O. Smith, 1996. Interaction of feeding time and temperature and their relationship to performance of the broiler breeder hen. Poult. Sci., 75: 34-41.

SAS, 1996. SAS User's Guide, statistics (6.2 $2^{\text {th }}$ ed.) Cary NC: SAS Institute Inc.

Shoukry H.M.S., M.M. Mahmoud and S.H. El-Berry, 1993. Preliminary study of the effect of melatonin injection on food intake and some physiological variables in male Japanese quail. Al-AzharJ.Agric. Res., 18: 14-22.

Simmons P.C.M., 1982. Effect of lighting regimes on twisted legs, feed conversion and growth of broiler chickens. Poult. Sci., 61: 1546. Abstr.

Teeter R.G. and M.O. Smith, 1986. Chronic heat stress and respiratory alkalosis: Occurrence and treatment in broiler chicks. Poult. Sci., 64:1060-1064.

Veltmann J.R., JR. F.A Gardner and S.S Linton, 1984. Comparison of rice hull products as litter material and dietary fat levels on turkey poult performance. Poult. Sci., 63: 2345-2351.

Wiernusz V.J. and R.G Teeter, 1993. Feeding effects on broiler thermobalance during thermoneutral and high ambient temperature exposure. Poult. Sci., 72: 1917-1924.

Wilson, H.R. and L.J. Keeling, 1991. Effect of time of feeding oviposition on time and production parameters in broiler breeders. Poult. Sci., 70: 254-259.

Wilson H.R., F.B. Mather, R.L.Brigmon, E.L. Besch., V.P. Dugan and N.Z. Boulus, 1989. Feeding time and temperature interactions in broiler breeders. Poult. Sci., 68: 608-616. 
Yahav S. and S.Hurwitz, 1996. Induction of thermotolerance in male broiler chickens by temperature conditioning at an early age. Poult. Sci., 75:402-406. 
تغيير وقت الإضاءة والتغذية لتخفيف التأثير الضار لصيف أسيوط الحار على أداء السمان الياباني

$$
\text { محمد فرغلى علم الدين فرغلى }
$$

قسم الإنتاج الحيوانسي والدواجن، كلية الزراعة، جامعة أسيوط، مصر

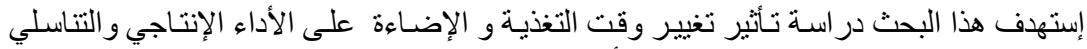

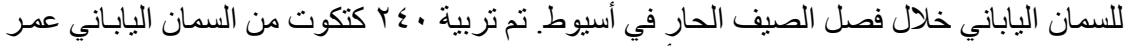

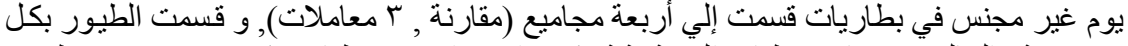

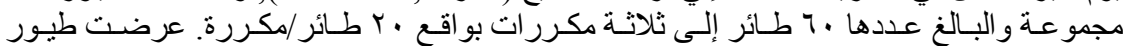

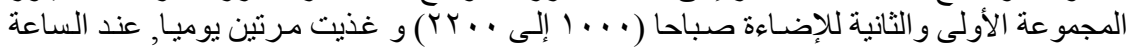

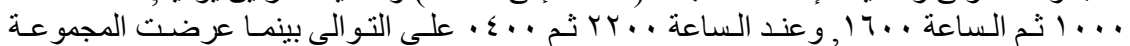

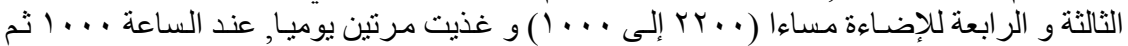

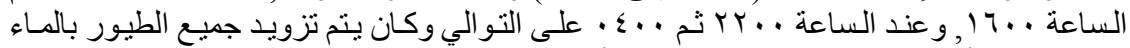

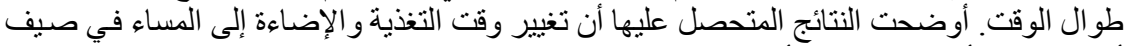

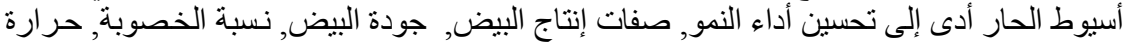

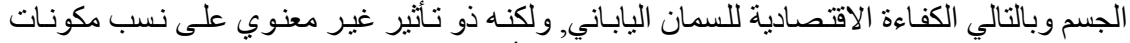

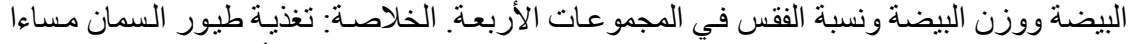

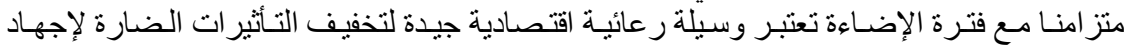
الحرارة العالية خلال فصل فئل الصيف في أسيوط. 